\title{
КОНЦЕПТУАЛЬНА ОСНОВА ЗАСТОСУВАННЯ ОНТОЛОГІї ДЛЯ СИСТЕМАТИЗАЦІї ЗНАНЬ В ОРТОПЕДї̈
}

М. М. Риган

Національний університет фізичного виховання і спорту України

\begin{abstract}
У статті підкреслюеться, що особливістю стратегії розвитку ортопедії є акцентована увага на розвиток високих технологій, сучасні тренди розвитку технологій ендопротезування, безперервне вдосконалення використовуваних конструкцій та інструментів. Представлено логіку та аксіоматику застосування апарату онтологій для впорядкування знань із ортопедії. В якості першого кроку створено онтологію з діагностики та лікування гонартрозу.
\end{abstract}

Ключові слова: онтологія, систематизація знань, стратегія розвитку ортопедії, феноменологія, тести оцінювання якості ортопедичних операцій.

\section{КОНЦЕПТУАЛЬНАЯ ОСНОВА ПРИМЕНЕНИЯ ОНТОЛОГИИДЛЯ СИСТЕМАТИЗАЦИИ ЗНАНИЙ В ОРТОПЕДИИ}

М. М. Риган

\author{
Национальный университет физического воспитания и спорта Украины
}

\begin{abstract}
В статье подчеркивается, что особенностью стратегии развития ортопедии является акцентированное внимание на развитии высоких технологий, современные тренды развития технологий эндопротезирования, непрерывное совершенствование используемых конструкций и инструментов. Представлены логика и аксиоматика применения аппарата онтологий для упорядочения знаний по ортопедии. В качестве первого шага создана онтология по диагностике и лечению гонартроза.
\end{abstract}

Ключевые слова: онтология, систематизация знаний, стратегия развития ортопедии, феноменология, тесты оценки качества ортопедических операций.

\section{FRAMEWORK OF ONTOLOGY TO SYSTEMATIZE THE KNOWLEDGE IN ORTHOPEDICS}

\section{National University of Physical Education and Sport of Ukraine}

M. M. Ryhan

\begin{abstract}
This article discusses the logic of orthopedics. There is emphasized that the distinctive side development strategy orthopedics is focused on the development of high technology, modern trends of the technology replacement, continuous improvement of designs and tools used. It's presented logic and axiomatics device application ontologies to organize knowledge in orthopedics. As a first step there is created an ontology for diagnosis and treatment of gonarthrosis.
\end{abstract}

Key words: ontology, knowledge structuring, development strategy of orthopedics, phenomenology, tests assessing the quality of orthopedic surgery.

Вступ. В історичному аспекті розвитку науки та технологій в останні роки виділяються два переломних періоди. Перший із них припускав відмову від раціоналістичного розуміння науки, а другий - сприяв зміненню принципів соціального конструктивізму та розумінню того, що знання має також онтологічний вимір.

Онтологія співвідносить повсюдно використовувані лікарями в їх практиці знання з причинами захворю- вань; етіопатогенетичними зв'язками між ознаками та захворюваннями; різними варіантами змінення значень ознак. По суті, реалізується принципово новий підхід до подання та візуалізації клінічних даних.

Онтологія лише частково є розділом феноменології. Як відомо, вона означає сукупність знань, що визначають взаємозв' язок між різними спостереженнями явищ (феноменів) відповідно до фундаментальної теорії, але таких, що безпосередньо з цієї теорії не

(c) M. M. Pитан 
наступають. Тобто, феноменологія є посередником між експериментом і теорією, вона більш абстрактна та багатокрокова в своїй логіці, ніж експеримент. Онтологічні жуявлення про науку більш широкі і дозволяють не тільки впорядкувати предметні знання, а й забезпечити зіставлення досліджень, окреслити перспективи розвитку предметних знань, прагматизм і багаторазовий реверсивний аналіз.

Онтологічні ж уявлення про науку ширші та дозволяють не тільки впорядкувати предметні знання, а й забезпечити зіставлення досліджень, окреслити перспективи розвитку предметних знань, прагматизм $і$ багаторазовий реверсивний аналіз.

Класичним відображенням значення онтологій $\epsilon$ їхня роль у медичних інформаційних системах (MIC), призначених для автоматизації роботи лікарень різного рівня - від районних до великих науково-дослідних центрів і таких, що забезпечують накопичення та підготовку інформації для ї̈ всебічного оперативного аналізу медичним і адміністративним персоналом. У МІС реалізується інтегрований єдиний інформаційний простір, де вся інформація, що проходить через медичний заклад, накопичується та доступна через автоматизовані робочі місця (АРМ) в сдиній базі даних.

Зрозуміло, вся інформація, що вноситься в МIC, повинна бути суворо структурована та доступна для подальшого аналізу. Відповідно, відмінною рисою МIC сучасного рівня є онтологічний підхід, що дозволяє представити різнорідну медичну інформацію в зручному вигляді для практичного та наукового аналізу. Одним із додатків онтологічного підходу є графічне представлення всіх подій і даних історії хвороби пацієнта в часі.

Мета дослідження: побудова концептуальних основ використання онтологічних конструкцій для впорядкування знань із деяких захворювань в ортопедії (на прикладі гонартрозу).

Матеріал і методи дослідження. В основу побудови онтології нами покладено узагальнення поглядів на патогенез остеоартрозу, переважно з точки зору ролі порушення синтетичних процесів у хондроцитах компонентів суглобового хряща, а також значення інших складових суглоба як цілісного органа, в якому знаходяться у взаємодії всі тканини, складові суглоба, в тому числі кістки та м'язи, що до нього прилягають.

Врахування будь-яких клінічних проявів захворювань, а також оцінювання ефективності проведених методів профілактики та лікування здійснювали за допомогою комплексу опитувальників. Усього вико- ристано понад 20 представлених у літературі опитувальників, у тому числі: «Оцінювання тяжкості гонартрозу (альгофункціональній індекс Лекена)»; WOMAC Osteoarthritis Index LK3; опитувальник SF36 (російськомовна версія) тощо.

В процесі вивчення збігу ознак, так само як і їх інтерпретації, з'ясувалося, що близькі оцінки зустрічаються не більше, ніж у 30-40\%. Усього отримано понад 600 оцінок і характеристик.

Результати та їх обговорення. Відмінною стороною стратегії розвитку ортопедії є акцентована увага на розвиток високих технологій. Сучасні тренди розвитку технологій ендопротезування, крім безперервного вдосконалення використовуваних конструкцій та інструментів, включають у себе впровадження методик ізольованого заміщення одного або декількох відділів колінного суглоба як альтернативу тотальній артропластиці, зменшення хірургічної агресії за рахунок використання менші інвазивних доступів, використання комп'ютерних навігаційних технологій і індивідуально виготовлених резекторних блоків для підвищення просторової точності орієнтації компонентів імплантата та кількісного контролю збалансованості суглоба в межах усісї амплітуди рухів, досягнення максимально можливого згинання в суглобі, оптимізацію протоколів ранньої реабілітації для прискорення відновлення функції суглоба й як наслідок більш швидкого повернення пацієнта до повсякденної активності, мультимодальну спрямованість післяопераційної аналгезіі, розробку комплексних стратегій із запобігання інтра- та післяопераційним ускладненням, зокрема крововтратам, хірургічній інфекції, тромбоемболії тощо.

Найбільший інтерес дослідників викликають матеріали та дизайн імплантатів, результати артропластики, інфекційні ускладнення, використання навігаціі, робототехніки та індивідуальних резекторних блоків.

Отже, на систематизацію знань увага дослідників звертається явно недостатньо.

Крім того, негативною рисою розроблюваних систем $є$ те, що коло їх застосування досить вузьке, оскільки вони являються або макетними версіями, або розроблені для певного медичного закладу і недоступні за рамками його локальної мережі.

3 іншого боку, системи медичної діагностики, що дають шाирокий доступ до своїх ресурсів із застосуванням сучасних мережевих технологій, поширюються явно недостатньо. Проте й вони не дозволяють експертам розширювати застосовувані в них бази знань.

Тому розроблення системи медичної діагностики, заснованої на знаннях експертів і моделі онтології, 
що враховує особливості медичних знань, в якій їх відображення має форму, найближчу до представлень експертів, і дозволяє не тільки визначати діагно3, а й пояснювати його, є актуальним завданням. Така система повинна проводити діагностику за прийнятний для лікаря час (незважаючи на те, що в її основі лежить нетривіальна онтологія медичних знань). Крім того, така система повинна надавати доступ якомога білышому числу користувачів, як для проведення медичної діагностики, так і для участі в накопиченні та вдосконаленні медичних знань про різні захворювання.

Бази знань предметної області та даних дійсності в інформаційному наповненні будуються відповідно до моделі онтології предметної області, що складається 3 трьох частин (модель спостережень, модель знань про захворювання, модель історії хвороби пацієнта).

Нами розпочато побудову онтології з діагностики та лікування «Гонартроз». За даними літератури, проблема ефективного лікування цієї групи захворювань набуває не тільки медико-соціального, але й економічного значення.

Незважаючи на пильну увагу до патології серед фахівців і достатньо довгий досвід спостережень, недостатня вивченість етіології та патогенезу дегенеративних хвороб суглобів, пізня діагностика, ускладнення, різноманіття варіантів прояву та перебігу - все це значно ускладнює вибір адекватного лікування [5].

На практиці пацієнту з гонартрозом пропонується стандартна схема лікування, що включає нестероїдні протизапальні препарати, тривалий прийом симптоммодифікуючих лікарських засобів (ЛЗ) - хондропротекторів $[6,8]$. У ряді випадків при супутніх захво-

\section{Література}

1. Современные тенденщии в ортопедии: артропластика коленного сустава / Р. М. Тихилов, Н. Н. Корнилов, Т. А. Куляба [и др.] // Травматология и ортопедия в России. - 2012. -№ 2 (64). - С. 4-15.

2. Багирова Г. Г. Остеоартроз: эпидемиология, клиника, диагностика, лечение / Г. Г. Багирова, О. Ю. Майко. - М. : Арнебия, 2005. - 222 с.

3. Коршунов Н. И. Современные подходы к фармакотерапии остеоартроза/Н. И. Коршунов, О. Б. Ершова// Consilium medicum. -2006 . - № 2. - С. $34-38$.

4. Мінцер О. П. Використання принципів медичної онтології для побудови сценарних моделей післядипломної освіти лікарів і провізорів / О. П. Мінцер, С. В. Денисенко, О. С. Стрижак// Медична інформатика та інженерія.-2013. -№2. - C. $18-23$.

5. Москаленко Ф. М. Задача медицинской диагностики и алгоритм ее решения, допускающий распараллеливание / рюваннях пацієнту призначають селективні інгібітори циклооксигенази (ЦОГ) - 2, а при стійкому болю в колінному суглобі проводиться внутрішньосуглобове введення глюкокортикостероїдів (ГКС).

Сучасні підходи до лікування спрямовані на зменшення патологічної симптоматики за допомогою різних методів: нефармакологічне лікування (фізичні вправи, зміна способу життя); фармакологічне лікування (нестероїдні протизапальні препарати, місцеве лікування); інвазивні методи лікування (внутрішньосуглобові ін'єкції, артропластика).

Природно, лікування хворих із дегенеративними захворюваннями суглобів має бути раннім, патогенетичним, комплексним і етапним. Проте все це можливо тільки на конщептуальному рівні. Важливо підкреслити, що системного погляду на лікування хворих не існує, також не обгрунтована й алгоритмічна складова.

Онтологію будували за класичним уявленням.

Всі концепти онтології створювали відповідно до множини класів і їх особливостей, класифікованих у вигляді певних ієрархій. Кожна з останніх має свою структуру та систему відносин між собою.

Висновки. 1. Стратегія лікування ортопедичних хворих обумовлюється дуже великим числом факторів: стадією та виразністю захворювання, супутніми процесами тоцо. Комплексне їх врахування повинно проводитися на основі застосування сучасних інформаційних методів, організованих у вигляді онтологій.

2. Важливим є створення аксіоматики діагностики та лікування на основі обгрунтованих принципів індивідуалізованого підходу, моніторингу стану пацієнтів, оцінювання ризиків лікування.

Ф. М. Москаленко // Информатика и системы управления. 2005. - №2 2(10). - С. $52-63$.

6. Палагин А. В. Онтологические методы и средства обработки предметных знаний : монография / А. В. Палагин, С. Л. Крывый, Н. Г. Петренко.- Луганск : ВНУ им. В. Даля, 2012. $-324 \mathrm{c}$.

7. Пешехонова Л. К. Клиническая эффективность хондропротекторов в комплексной терапии остеоартроза коленных суставов / Л. К. Пешехонова, Т. Н. Кузовкина, Д. В. Пешехонов// РМЖ. -2009. - №21. - С. 1486-1489.

8. Gapl M. Surgical treatment of the knee osteoarthritis / M. Gapl// Reumatizam. -2005. - № 52 (2). - P. 52-55.

9. Gruber T. R. A Translation Approach to Portable Ontology Specification/T. R. Gruber// KnowledgeAcquisition. - 1993. Vol. 5. - P. $199-220$. 